to jedynie efekt pewnej mody oraz cyrkulujących w mediach wyobrażeń na temat tego, jak powinno wyglądać współczesne państwo narodowe. Jej opinię na temat możliwości, które stwarza proces zarządzania wizerunkiem takiej jednostki terytorialnej jak kraj, oddaje jeden z podtytułów: Soft power and hard reality. Valaskivi wyraża tym samym swój sceptycyzm wobec obietnicy głoszonej przez aktorów zaangażowanych $\mathrm{w}$ działania mające na celu podnoszenie atrakcyjności marek narodowych ${ }^{10}$.

Nastawienie autorki i miejscami zbyt widoczne osobiste zaangażowanie w opisywaną tematykę można uznać za największy mankament recenzowanej publikacji. Nie powinien on jednak wpływać na ogólną ocenę książki, szczególnie wśród odbiorców obeznanych z założeniami analizy dyskursu w wydaniu krytycznym. Pod tym względem Cool Nations doskonale wpisuje się w dotychczasowy stan badań na temat motywacji i skutków brandingu narodowego i stanowi lekturę obowiązkową dla czytelników zainteresowanych tą tematyką.

${ }^{10}$ Ową obietnicę najlepiej oddaje polski tytuł książki jednego z najbardziej rozpoznawalnych zwolenników brandingu narodowego, Simona Anholta. Por. idem, Sprawiedliwość marek. Jak branding miejsc i produktów może uczynić kraj bogatym, dumnym i pewnym siebie, przeł. M. Hereźniak, M.A. Boruc, Warszawa 2006.

\title{
Grzegorz Wilga
}

Uniwersytet Wrocławski

\section{Fantazje kreujące rzeczywistość}

DOI: $10.19195 / 0867-7441.23 .17$

Recenzja: Jolanta Szymkowska-Bartyzel, Nasza Ameryka wyobrażona. Polskie spotkania z amerykańska kultura popularna po roku 1918, Księgarnia Akademicka, Kraków 2015, ss. 423.

Słowa kluczowe: popkultura, Stany Zjednoczone, spotkanie kultur, kultura amerykańska

Keywords: popculture, the United States, meeting of cultures, American culture

Stany Zjednoczone są uznawane za niekwestionowane supermocarstwo i państwo o ogromnym znaczeniu. Wynika to nie tylko z potencjału politycznego igospodarczego,lecztakżekulturowego.Zpunktuwidzeniabadańkulturoznawczych nie ma więc większych wątpliwości co do sensu badania znaczenia amerykańskiej kultury. Całościowemu przyjrzeniu się wpływowi amerykańskiej popkultury na polskiego odbiorcę poświęciła swoją pracę dr Jolanta Szymkowska-Bartyzel, 
filmoznawczyni i adiunkt w Instytucie Amerykanistyki i Studiów Polonijnych na Uniwersytecie Jagiellońskim w Krakowie, w wydanej w 2015 r. publikacji Nasza Ameryka Wyobrażona. Polskie spotkania z amerykańska kultura popularna.

Tytuł pracy zdradza równocześnie interesujące zamierzenie autorki odnoszące się do celu pracy. Nie jest nim bowiem obiektywne przedstawienie „prawdziwej” Ameryki ${ }^{1}$, a jedynie mitów i wyobrażeń jej towarzyszących w umysłach Polaków w XX i XXI w. Jak wskazuje Szymkowska-Bartyzel, ,amerykańska historia, kultura i polityka są utkane $\mathrm{z}$ gęstej siatki rozmaitych mitów. [...] Z przekazów tych wyłania się Ameryka zafałszowana, nawiązująca jedynie do kraju zwanego Stany Zjednoczone, jego historii i kultury" (s. 31). W przeszłości źródłem mitu o USA były ustne przekazy osób, które zdecydowały się w różnych celach przebyć drogę „,za wielką wodę”, czy też listy, w których prezentowali dany obraz Ameryki. Obecnie głównym twórcą „mitologii” o Ameryce jest kultura popularna, której autorka poświęca całą swoją książkę. Głównie więc do analizy badawczej posłużył amerykański film, prasa, muzyka czy literatura i jej odbiór przez Polaków w ciągu dziesięcioleci.

Warto zwrócić uwagę na wybrany przez kulturoznawczynię tytuł pracy sugerujący, iż kontakty między obydwoma krajami miały charakter „spotkania”. Mimo że w badaniach kulturoznawczych toczy się dyskusja dotycząca tego, jaka w rzeczywistości jest natura ekspansji kultury amerykańskiej — czy jest to narzucanie hegemonii i kulturowa dominacja, proces samoamerykanizacji, czy może w końcu jakaś z form hybrydowych — to jednak w pracy proponowaną koncepcją opisującą charakter tych kontaktów jest formuła „spotkania”. Zakłada ona zarówno szerokie spektrum możliwego postrzegania kulturowych kontaktów, jak i brak „charakteru wartościującego” (s. 11).

Publikacja została podzielona na pięć rozdziałów. W pierwszym autorka umiejscawia tematykę pracy $\mathrm{w}$ dyskursie naukowym dotyczącym Ameryki przedstawia wspomnianą już kategorię Ameryki wyobrażonej oraz popularne $\mathrm{w}$ przestrzeni publicznej pojęcie amerykanizacji. Nie jest ono w pełni tożsame ani z procesem globalizacji, ani modernizacji, a także z opisywanymi pojęciami westernizacji, macdonaldyzacji czy disneizacji. Autorka wskazuje na podobieństwa i różnice tych pojęć ${ }^{2}$. W drugim rozdziale przybliża europejski kontekst spotkania z Ameryką, wskazując na doświadczenia trzech znaczących krajów Europy w kontaktach z USA: Wielkiej Brytanii, Francji i Niemiec. Ukazanie ich różno-

1 Jak choćby w publikacji Marka Gołębiowskiego Dzieje kultury Stanów Zjednoczonych (Warszawa 2004), w której autor prezentuje w sposób syntentyczny główne trendy i motywy amerykańskiej kultury na przestrzeni całej historii tego kraju, bez wchodzenia w szczegóły nad wpływem tej kultury na inne kraje.

${ }^{2}$ Warta uwagi jest również publikacja Radosława Zenderowskiego, Krzysztofa Cebula i Mateusza Kryckiego Międzynarodowe stosunki kulturalne (Warszawa 2010), w której Zenderowski ukazuje zależności między globalizacją i regionalizmem na podstawie publikacji Dżihad kontra McŚwiat (Jihad vs. McWorld. How Globalism and Tribalism Are Reshaping the World, New York 1995) Benjamina R. Barbera.

Literatura i Kultura Popularna 23, 2017

(C) for this edition by CNS 
rodnych relacji (Wielka Brytania - symetryczne i partnerskie kontakty, Francja — próby bronienia się przed amerykanizacją, Niemcy — kultura amerykańska jako narzucony model) pozwoliło na spojrzenie w szerszym kontekście na odmienne możliwości recepcji i interpretacji kultury amerykańskiej. Kolejne cztery rozdziały poświęcone są już w całości odbiorowi popularnej kultury amerykańskiej na gruncie polskim. Autorka podzieliła je zgodnie z ważnymi wydarzeniami światowej i polskiej historii: okres międzywojenny (1918-1939), okres Polski Ludowej (1945-1989), okres transformacji (1989-2004) oraz Polska współczesna (od 2004 r. do czasów obecnych).

Analiza stu lat relacji amerykańskiej kultury popularnej z Polską pozwala na określenie dominujących w tym czasie nurtów, które można podzielić w sposób następujący: Ameryka jako symbol nowoczesnego i bogatego świata; Ameryka jako kulturowy hegemon, wobec którego inne kultury powinny się dystansować; oraz Ameryka jako nierealne wyobrażenie oparte na własnych potrzebach i oczekiwaniach. Stany Zjednoczone jako wzór do naśladowania i ucieleśnienie nowoczesności były obrazem szczególnie popularnym w okresie międzywojennym i po transformacji ustrojowej w latach 1989-2004. W pierwszej fazie, w okresie międzywojennym, kulturowy transfer z USA odbywał się przede wszystkim na podstawie trzech zjawisk przedstawionych przez autorkę: amerykańskiego (głównie hollywoodzkiego) kina, muzyki jazzowej oraz samochodu. Wszystkie trzy fenomeny ukazywały Amerykę jako kraj nowoczesny i liberalny światopoglądowo. Stanowiły atrakcyjny obraz dla Polaków, nawet jeśli był on recypowany jeszcze przez niewielką część społeczeństwa. Przykładowo - liczba samochodów przypadająca na 10 tys. mieszkańców w Polsce w 1939 r. wynosiła zaledwie dziesięć sztuk, podczas gdy w USA - 2288 (s. 154). Mimo terytorialnej odległości to właśnie samochody amerykańskie, a nie europejskie, zdominowały przedwojenny rynek motoryzacyjny w Polsce, podobnie jak muzyka jazzowa. Jedynie pod względem kina liczba produkcji amerykańskich na polskim rynku wobec wszystkich produkcji była relatywnie niewielka (ok. 60\%) w porównaniu z innymi krajami europejskimi.

Pierwsze spotkanie z kulturą amerykańską na tak szeroką skalę zostało gwałtownie przerwane II wojną światową i wejściem Polski w orbitę państw bloku sowieckiego po jej zakończeniu. Następujący po tym zdarzeniu niemal półwieczny okres komunizmu zmienił charakter spotkania Polaków z kulturą amerykańską. W oficjalnej propagandzie państwowej - nie licząc pierwszych powojennych lat do 1948 r., kiedy to podejście do kultury amerykańskiej było jeszcze neutralne USA symbolizowały moralne zepsucie, społeczne problemy oraz agresywną kulturową i polityczną hegemonię. Warto w tym miejscu odnieść się choćby do wystawy z 1953 r. pt. Oto Ameryka i jednego z odcinków Wytwórni Filmów Dokumentalnych i Fabularnych o tym samym tytule, w którym obraz USA jako uosobienia wszelkiego zła był szczególnie akcentowany. Z kolei postawa obywateli wobec kraju za oceanem była w większości pozytywna. Stany Zjednoczone w dalszym ciągu pełniły 
funkcję mitu symbolizującego nowoczesność, wolność i liberalizm. Będąc też przeciwieństwem lansowanego w Polsce Ludowej stylu życia, stanowiły również symbol oporu wobec władzy - jak przykładowo dżinsowe spodnie i rock'n'roll w latach 60 ., a potem polska muzyka punkowa z lat 80 . Warto jednak zwrócić uwagę na podawane przez autorkę liczne przykłady „wyhamowywania” buntu i przemiany artefaktów buntu - jazzu, rock'n'rolla czy dżinsów. Z czasem przeistaczały się one w spolonizowane, umasowione substytuty, które straciły kontestacyjny charakter — polską wersję jazzu, czyli akceptowany przez władzę big beat, czy produkowane w Polsce dżinsy (materiał do ich produkcji nazywano wówczas „teksasem”), niemające już takiej aury oryginalności i buntu jak dżinsy amerykańskie.

Po obaleniu komunizmu rozpoczął się etap często bezrefleksyjnego przyjmowania amerykańskiej kultury, znacznie ułatwiony dzięki coraz większej liczbie nowoczesnych technologii. W latach 90 . było to wideo i magnetowidy, później - płyty CD i Internet.

Tym, co łączy ponad sto lat obcowania polskiego odbiorcy z amerykańską kulturą, bez względu na sytuację społeczno-polityczną i dominujące tendencje, jest postrzeganie Stanów Zjednoczonych często przez pryzmat mitów, wyobrażeń i fantazji, dzięki którym Polacy mogli kreślić i nadawać kształt swoim aspiracjom. Pomocne w tym było położenie Ameryki — „odległej ziemi zza mórz i oceanów, do której trudno dotrzeć, ale za to można o niej snuć nieograniczone fantazje" (s. 125). Autorka podaje bardzo liczne przykłady tworzenia zafałszowanych wizji ze wszystkich okresów obcowania Polski z kulturą amerykańską. Był to choćby jeden z wielu ruchów kontestatorskich PRL-u — bikiniarze, których realna znajomość Ameryki była bardzo nikła, a umiejętność imaginacji — wprost proporcjonalna do braku wiedzy o przedmiocie swoich marzeń. „Poza bikiniarskim kostiumem, który był bardzo luźnym nawiązaniem do amerykańskiego oryginału, żeby nie powiedzieć czystą imaginacją, [...] słuchanie jazzu, przeważnie przy dość powierzchownej jego znajomości" (s. 191) cechowało tę subkulturę. W latach 80. ideę fantazjowania i marzenia o Stanach Zjednoczonych trafnie oddawały filmy: Pociag do Hollywood (reż. R. Piwowarski, Polska 1987) — o bufetowej w jednym z polskich pociągów, pragnącej w rzeczywistości kariery w amerykańskiej fabryce snów, czy Nowy Jork, czwarta rano (reż. K. Krauze, Polska 1988) o młodych ludziach z prowincji, dążących do odwiedzenia metropolii Wschodniego Wybrzeża.

Od niedawna na popularności zyskał nowy trend postrzegania Stanów Zjednoczonych — krytyczne podejście, wywołane najpierw atakami na World Trade Center z 2001 r., a potem rozpoczęciem wojny w Iraku przez USA wraz z jednoczesnym wejściem Polski do Unii Europejskiej. Ten bardziej refleksyjny ton trwa do dziś. Równocześnie amerykańska kultura popularna zmieniła swój charakter. Pojawienie się Internetu sprawiło, że odbiorca danej treści stał się również jej twórcą, a kultura amerykańska —żeby mogła być odbierana wszędzie na świecie — ulega procesowi deamerykanizacji (s. 354) poprzez wchodzenie w polemikę z typowo amerykańskimi wartościami przy równoczesnej rezygnacji z promowania tych wartości.

Literatura i Kultura Popularna 23, 2017

(C) for this edition by CNS 
Szeroki przegląd różnych aspektów spotkania Polaków z kulturą amerykańską oraz jasna struktura publikacji to duże zalety recenzowanej książki. Jej lektura może okazać się wartościowa dla wszystkich pokoleń Polaków — zarówno dla osób pamiętających kulturę amerykańską z lat 40. i 50. XX w., jak i najmłodszego pokolenia. Pozwala bowiem lepiej zrozumieć społeczeństwo, motywy działania i siłę tworzonych wyobrażeń o Ameryce, które często - chociaż nierealne miały rzeczywisty wpływ na historię Polski.

\section{Jacek Ladorucki}

Uniwersytet Łódzki

\section{Lepkie, brudne cukierki... Zapomniana żydowska literatura z miasta Lodzi}

DOI: $10.19195 / 0867-7441.23 .18$

Recenzja: Jisroel Rabon, Batuty: powieść o przedmieściu, red. Krystyna Radziszewska, Natalia Krynicka przy współpracy Izabeli Olejnik i Jacka Walickiego, przełożyły z jidysz Natalia Krynicka i Izabela Olejnik, Wydawnictwo Uniwersytetu Łódzkiego, Łódź 2016, ss. 175 [+2].

Słowa kluczowe: Jisroel Rabon (1900-1941), literatura żydowska, studia literaturoznawcze, medioznawstwo, socjologia kultury, historia społeczna miasta Łodzi

Keywords: Jisroel Rabon (1900-1941), Jewish literature, literary studies, media studies, sociology of culture, social history of the city of Łódź

Historia łódzkiej wieloetnicznej popkultury nie jest powszechnie znana ani doceniana. Na przełomie lat 50. i 60 . XX w. Janusz Dunin zbierał materiały na temat kultury miejskiej, co zaowocowało publikacją $W$ Bi-Ba-Bo i gdzie indziej. O satyrze i humorze z Miasta Łodzi od Rozbickiego do Tuwima. Było to studium łódzkiego folkloru miejskiego, w którym badacz uchwycił autentyczny klimat satyry i kabaretu z dziejów miasta nad Łódką. Twórczość z pogranicza literatury, publicystyki i folkloru, podpisana nazwiskami Wiktora Dłużniewskiego, Henryka Frenkla, Artura Gliszczyńskiego lub anonimowa, publikowana w gazetach, jednodniówkach, kalendarzach i ulotkach pokazywała, jak „ludność fabryczna bawi się poza domem i najchętniej wolne chwile przepędza $\mathrm{w}$ ulubionych ogródkach i piwiarniach"1.

${ }^{1}$ Janusz Dunin ukazał działalność pierwszego łódzkiego pisma satyrycznego (tygodnik „Śmiech”) oraz historię kabaretu w Łodzi ze szczególnym uwzględnieniem tytułowego „Bi-Ba-Bo”, z którym związany był młody literat — Julian Tuwim. W 2010 r. nakładem wydawnictwa Officyna 